\title{
The Development of the Chinese Character Knowledge in Hong Kong Cantonese-speaking Children
}

\author{
Emily Yee Man CHEUNG \\ Department of Chinese, Hong Kong Institute of Education \\ 10, Lo Ping Road, Tai Po, Hong Kong, SAR, China \\ E-mail: ymcheun@ied.edu.hk
}

Received: October 5, $2010 \quad$ Accepted: December 10, $2010 \quad$ doi:10.5539/ass.v7n5p25

\begin{abstract}
This paper reports a study on the development of the Chinese character recognition knowledge in 2942 Hong Kong Cantonese-speaking elementary school children. 2357 Chinese characters in the Revised Chinese Character List (2007) for Hong Kong Cantonese-speaking elementary school children were divided into 36 versions of test booklets to test the school children's character recognition knowledge. Each test booklet consisted of a list of 130 to 132 character items, with $50 \%$ of linkage to the next test booklet in the series. The results suggest that the children's character recognition knowledge grows as they progress in their education levels. The acquisition during the period of level two is rapid and marked. By level three, the school children's ability reaches $91 \%$ coverage of the Chinese characters in the Revised Character List (2007). Furthermore, the study has classified the 2357 Chinese characters in the Revised Chinese Character List (2007) by grade level.
\end{abstract}

Keywords: First language acquisition, Language development, Chinese character recognition, Hong Kong elementary education

\section{Introduction}

Language development is a crucial area of research because it relates closely to cognitive development (Anderson \& Freebody, 1981; Terman, 1916; Wechsler, 1949) and academic achievement (Miller, 1988; Stanovich, 1986). In Chinese language development, characters serve as basic building blocks in understanding and generating sentences and in reading competence, especially for pupils aged from 6 to 9 (Cheung, 2007). Studies of character knowledge can therefore provide a window on the process of Chinese language acquisition as a whole. Measures on Chinese character knowledge can thus be used as a proxy for the language ability of the pupils.

\subsection{Chinese character and Chinese word}

In human language, there is a link between a given writing system and a particular variety of spoken language. The writing system represents utterances of that particular spoken variety (Sampson, 1985). The Chinese writing system is morphemic (Kratochvíl, 1968), in which Chinese scripts are representing Chinese morphemes rather than Chinese words. There are no inflections in Chinese language. Grammatical relations are established either by word order or by the use of independent grammatical particles. Most of the time, word, or vocabulary, in Chinese language consists of more than one morpheme. For instance, the Chinese word, or Chinese vocabulary 電車 'tram' is made up of two free morphemes 'electricity-car'. The quadrisyllabic fixed combination 一見鍾情 'love at first sight' is made up of four morphemes. Therefore, in principle, there is one symbol in the Chinese scripts for one morpheme. Such a symbol is called a Chinese character. An individual Chinese character is always pronounced in a given spoken variety, for instance, in Cantonese in the Hong Kong Community. Linguistically, each Chinese character with a standard written form is linked to a canonical spoken form for Cantonese. For instance, the Chinese character 字 'character' is linked to the spoken Cantonese canonical form [zi6], the word 欽佩 'admire’ which consists of two Chinese characters is linked to the spoken Cantonese canonical form [jam1 pui3]. Whenever the Hong Kong Cantonese-speaking school children learn the Chinese character, they simultaneously learn the standard Cantonese pronunciation and the meaning the Chinese character represents.

\subsection{The Revised Chinese Character List}

As early as 1990, the Hong Kong government had developed the first Chinese Character List (Hong Kong Curriculum Development Unit, 1990) for elementary school children in Hong Kong. The Chinese characters in the 
Character List (HKCDU, 1990) were classified into six grade levels (i.e. level one to level six, levels one to six in Hong Kong education correspond to grades one to six in the west) and formed an important basis for the Chinese language curriculum at elementary school levels for 17 years until 2007. Nevertheless, because of the political changes and their consequential impact on societal goals and education processes, the Character List (HKCDU, 1990) was deemed inadequate by the Hong Kong Education Bureau, and was replaced by a Revised Chinese Character List (Hong Kong Curriculum Development Unit, 2007) in 2007. In 2007, the Hong Kong Curriculum Development Unit published the Vocabulary List (Hong Kong Curriculum Development Unit, 2007) for Hong Kong elementary education. The Vocabulary List (HKCDU, 2007) contains 9680 textbook and newspaper words. The entries are based on five sources: the word lists of the Chinese language elementary textbooks in China, the Neidi Tongyong Ciyubiao (the Commonly Used Word List) (Guojia Yuyan Wenzi Gongzuo Weiyuanhui [State Language Work Committee], 2006) in China, the Taiwan Jiaoyubu Changyong Ciyubiao 1998 (the Commonly Used Word List 1998) (Ministry of Education, 1998 )from Taiwan, the Vocabulary List (HKCDU, 1996) from Hong Kong and the Commonly Used Word Corpus (2003) from the Hong Kong Polytechnic University. At first, all the words in both the word lists of the Chinese language elementary textbooks in China and the Vocabulary List (HKCDU, 1996) in Hong Kong were entered. Then 15000 of the high-frequently used words in each of the remaining three sources were selected. This resulted in five data sets of textbook and newspaper words from China, Taiwan and Hong Kong. Then the commonly occurring words in at least three data sets were included as the main entry words. Additional word entries included idioms, simple classical Chinese words, proper nouns and transliteration words. Thereafter, a character list of 3541 Chinese characters was generated from this vocabulary list. Both the vocabulary and character lists were classified into two key stages, namely, key stage one (i.e. level one to level three) and key stage two (i.e. level four to level six). Thus, the Vocabulary and Character Lists for Hong Kong Elementary Education (HKCDU, 2007) have replaced the former Vocabulary List (HKCDU, 1996) and the former Character List (HKCDU, 1990) respectively and have served as the prescriptive references for language learning and assessment for elementary education in Hong Kong. In the Revised Chinese Character List (2007), there are 2357 entries for key stage one school children and 1184 entries for key stage two school children.

\subsection{Receptive character knowledge and productive character knowledge}

Nation (1990) identified two levels of vocabulary knowledge, namely, receptive and productive vocabulary knowledge. Receptive vocabulary knowledge refers to the learners' ability to recognize and understand the vocabulary in reading and listening whereas productive vocabulary knowledge is vocabulary the learners produced in writing and speaking. The learners will acquire the receptive knowledge initially (Carey, 1978) and through intentional learning (Chall,1987; Nagy \& Anderson, 1984; Nagy \& Herman, 1987) and practice and drill (Paribakht \& Wesche, 1996; Senechal, 1997, T'sou, Kwan and Liu, 1997), the receptive knowledge will be elevated to the productive knowledge. In Chinese language, every Chinese character stands for a Chinese morpheme which usually is a single syllable together with its respective meaning (Kratochvíl, 1968). Most of the time, the Chinese vocabulary, or word, comprises more than one morpheme and thus, is written with more than one character. Receptive Chinese character knowledge, therefore, refers to the learners' ability to recognize and understand the 'what' aspects of the characters, that is to say, knowing what the character sounds like and the meaning the character represents. Productive Chinese character knowledge, then, refers to whether the learners are able to master the 'how' aspects of the characters, that is, knowing how to write and use the character.

\subsection{Previous studies on Chinese character knowledge}

Chinese character knowledge studies that provide examples of the current state of the field in Taiwan, China and Hong Kong are reviewed.

Ke and Wu (1987, 1990 \& 1993) successfully compiled both a high-frequency character list and a difficult character list for Taiwan level one, level two, level three and level six school children respectively. There are 968 high-frequency characters and 175 difficult characters for level one, 1778 high-frequency characters and 196 difficult characters for level two, 3258 high-frequency characters and 419 difficult characters for level three, 4138 high-frequency characters and 246 difficult characters for level six. Ke et al. (1987, 1990 \& 1993), therefore, provide a reference for writing pedagogical texts and designing Chinese language assessment not only for Taiwan elementary school children, but also for cross-regional educators and researchers on studying character development of native Chinese children.

In China, Li, Peng and Shu (2006) explored the emergence and development of Chinese orthographic awareness and the correlation between orthographic awareness and Chinese characters in 474 preschool and elementary school children. Figures, ill-component non-characters, ill-structure non-characters, pseudo-characters and real 
characters were used as stimuli to test the participants' judgment on legal characters. The results showed that orthographic awareness did not appear until level one. Preschool children could only discriminate figures among stimuli whereas elementary school children were aware of the legality of the component and the structure of the Chinese characters. The awareness of character structure was more easily acquired than the awareness of character component in school children from China.

Li (1999) in Hong Kong developed a Preschool Chinese Literacy Scale for assessing the Chinese character knowledge of kindergarten children aged from 2 to 6 years. The Scale consisted of 200 Chinese characters and was tested in Hong Kong, Beijing and Singapore. The results provide converging empirical evidence that the Scale is primarily reliable.

Tse, Marton, Ki and Loh (2007) proposed an integrative approach to teach Chinese characters for Hong Kong school children. Apart from teaching the Chinese characters at context and word levels, the language teachers can help the school children to make use of the semantic radicals and the phonetic radicals of the Chinese characters to infer the meaning of the unfamiliar Chinese characters.

Cheung (2007) selected 260 Chinese characters randomly from the Character List (1990) to test the character production knowledge of 485 level two school children in Hong Kong. The knowledge of the sound, form and meaning of the selected characters was tested. The findings reveal that the school children's knowledge of sound takes precedence, the meaning comes second and the form is third.

In all, the above review of the current studies suggests various focuses on Chinese character knowledge research. Nonetheless, it convinces us that Chinese character knowledge research is a crucial area in language acquisition. In Hong Kong, the information of Chinese character acquisition in native Chinese children is lacking. In these circumstances, investigation into Chinese character knowledge development with reference to the Revised Chinese Character List (2007) would add information to the body of Chinese character research.

\subsection{The purpose of the study}

The present study investigates the development of the acquisition of the primary aspect of Chinese language, the Chinese character, by early elementary school children in an Asian city, Hong Kong. It aims to provide empirical evidence on the Chinese character recognition knowledge on the basis of the Revised Chinese Character List (2007). Currently, there is no classification of grade levels of the Chinese characters in the Revised Chinese Character List (2007). Therefore, a second purpose of the study is to classify the Chinese characters for early elementary school children in the said 'List' by grade levels. Thus, the teachers can align their teaching with the early elementary school children's character knowledge as well as the proposed Chinese character grade level lists (see Appendices 1 to 4).

\section{Method}

\subsection{Participants}

The participants were 2942 elementary school children, approximately equal numbers of male and female, studying in level one $(n=936)$, level two $(n=974)$ and level three $(n=1032)$ in eight Hong Kong elementary schools. The distribution is indicated in Table 1.

\section{Insert Table 1 about here}

The elementary schools that participated in this study, as reported by the respective school principals, were at the middle range of the academic achievement continuum in the elementary school population in Hong Kong. The pupils had normal intelligence, no speech impediments or language disabilities, as reported by their parents and teachers, and were between 6 and 7 years of age in level one, 7 and 8 years of age in level two, and 8 and 9 years of age in level three at the time they participated in the study. They were native speakers of Cantonese and learned the written form of Modern Standard Chinese from formal instruction in school. Their schools followed the syllabus of Chinese language education as recommended by the Education Bureau in Hong Kong. In summary, the pupils were studying the same curriculum, speaking Cantonese as their mother tongue and using Modern Standard Chinese in writing. The Hong Kong Education Bureau has divided the schooling from elementary to secondary into four key stages (Learning to Learn - The Way Forward in Curriculum Development, 2001; The New Academic Structure for Senior Secondary Education and Higher Education - Action Plan for Investing in the Future of Hong Kong, 2005), namely, key stage one (junior elementary, level one to level three), key stage two (senior elementary, level four to level six), key stage three (junior secondary, level seven to level nine) and key stage four (senior secondary, level ten to level twelve). The research sample in this study was the elementary school children of key stage one (i.e. level one to level three). Thus, for this study, the sample reflects the pupil 
population at key stage one at the middle range of the academic achievement continuum and, specifically, reflects the level difference, that is to say, the difference in level one, level two and level three, in early elementary school children of the Cantonese-speaking community in Hong Kong.

\subsection{Instruments}

The instrument employed in this study used 36 versions of Chinese character test booklets. Each test booklet contained from 130 to 132 character items.

Given that the 2357 Chinese characters for key stage one to be tested are too many for any single participant, they were divided into 36 lists of between 65 and 66 Chinese characters each such that the tests were not too physically demanding for the school children. The allocation of the Chinese characters into the 36 lists was by a random process in order to ensure that the difficulty levels across the 36 lists were approximately equal. Thus, 36 versions of the test booklets were formed from the lists to provide comprehensive coverage of the 2357 characters in the Revised Chinese Character List (2007). A 50\% linkage across the test booklets was established by tagging the list in the subsequent test booklet to the end of the previous one (i.e. the second half of the previous booklet became the first half of the following booklet). For instance, the test booklet A consisted of lists 1 and 2. The test booklet B consisted of lists 2 and 3. The last booklet consisted of lists 36 and 1. Such an arrangement ensured adequate connectivity between the test booklets. Hence, each test booklet was made up of a list of between 130 and 132 test items, each test item being one Chinese character, and there was a $50 \%$ linkage between consecutive test booklets in the series. Each participant was asked to complete one test booklet only.

\subsection{Procedures}

The test was carried out in a regular Chinese language class, under the supervision of the investigator. The test booklets were distributed sequentially to the participants according to their student identity number. The participants responded to each Chinese character item in the booklet by indicating whether or not they recognized the character, thus yielding a dichotomous response. For the participants in level one, the investigator read out the characters one by one to the school children. The participants in level two and level three completed the test during the class time. Also, all participants were reminded that their responses were anonymous so they were able to respond as truthfully as possible. Most participants were able to complete the entire test in 30 minutes.

The data were compiled into 36 data files, one for each test booklet, with $50 \%$ linkage across the files. Each file had between 130 and 132 Chinese character items. Each character item was attempted by between 42 and 58 participants at level one, 43 and 61 participants at level two and 42 and 64 participants at level three.

While gender differences in western language development studies are often examined, they nevertheless maybe found in one context but then not observed in another (Gleason \& Ely, 2002). In most Chinese language acquisition studies, significant language differences between boys and girls are rarely observed (Li, 1999; Li, Peng, \& Shu 2006; Tse, Marton, Ki \& Loh, 2007; Tsou, Lee, Tung, Kwan, \& Au, 2000). For this reason, the research sample was not split on gender lines in the analysis. The SPSS 17.0 for Windows (2008) was used for the analysis of the data.

\section{Results}

This section reports the analyses of the data which include: (a) children's Chinese character recognition knowledge; (b) basic Chinese character mastery for all levels; (c) the percentage of learning in Chinese character recognition from one level to the next. Levels one, two and three in Hong Kong education correspond to grades one, two and three in the west. Level will be used in what follows.

\subsection{Children's Chinese character recognition knowledge}

Table 2 presents the school children's performance in the recognition of the 2357 characters. In Table 2, it can be seen that level-three children performed better than the level-two children (recognition $87 \%$ vs. $75 \%$ ) and the level-one children (recognition $87 \%$ vs. $54 \%$ ). Level-two children performed better than the level-one children (recognition $75 \%$ vs. $54 \%$ ) as well. This indicates that the children at higher grade levels were found to have more knowledge in Chinese character recognition than children in lower grades. This provides strong evidence that the children's character recognition knowledge grows as they progress in their education levels.

\section{Insert Table 2 about here \\ 3.2 Basic Chinese character mastery for all levels}

In order to indicate the school children's mastery of Chinese characters at each level, a cut-off of .6 was used for all levels. In other words, the character items which had a mean of .6 and above were classified as basic mastery 
characters for that particular level. The cut-off of .6 was chosen since most Chinese classroom teachers would accept a character item recognized $60 \%$ and above as being understood by school children for that specific grade level.

\subsubsection{Level-one Mastery Characters}

Level-one children showed basic mastery on 963 characters of the 2357 characters presented to them. In other words, 963 items, or $41 \%$ of the 2357 characters were recognized by $60 \%$ and above of the level-one children. As Figure 1 shows, level-one school children had a mean of $.83(S D=.13)$ on the 963 basic mastery characters. Consequently, 1394 non-mastery level-one characters (i.e. those below the .6 cut-off) were left for further investigation at level-two. The large spike in the histogram around 1 (perfect recognition) is due to a few particularly easy items that Chinese school children know before entering level-one (i.e. they have learned these characters in kindergarten). A few examples of such character items include 中 'middle', 妹 'young sister', 是 'am, are, is', 美 'pretty', 九 'nine', 口 'mouth', 天 'sky', 白 'white', 車 'car', 魚 'fish' and 雨 'rain'. The list of the 963 level-one basic mastery characters is shown in appendix 1.

\subsubsection{Level-two Mastery Characters}

\section{Insert Figure 1 about here}

Level-two children's recognition knowledge on the level-one 963 mastery characters was tested first. Level-two children showed basic mastery of all level-one 963 items $(M=.94, S D=.06)$. The performance of level-two children on the non-mastery level-one 1394 characters was tested next. Level-two children showed considerable learning (level-two children: $M=.62, S D=.21$ vs. level-one children: $M=.34, S D=.14$ ) on the 1394 characters. Using the .6 cut-off, level-two children showed basic mastery on 802 of these characters. That is, they showed mastery on $58 \%$ of the characters not mastered by level-one children. Therefore, the total number of characters mastered by level-two children is 1765 , or $75 \%$ of the 2357 characters. This represents a learning increment of about 34\% over level-one school children. Indicated in Figure 2, level-two school children had a mean of .77 (SD $=.10$ ) on their 802 basic mastery characters. Consequently, 592 non-mastery level-two character items (i.e. those below the .6 cut-off) were left for further investigation at level-three. The list of the 802 level-two basic mastery characters is shown in appendix 2 .

\section{Insert Figure 2 about here \\ 3.2.3 Level-three Mastery Characters}

Before looking into the level-three children's performance on the 592 non-mastery level-two characters, the level-three children's recognition knowledge on the 802 level-two mastery characters was tested. Level-three children showed basic mastery of all level-two 802 items $(M=.91, S D=.08)$. The performance of level-three children on the non-mastery level-two 592 characters was tested next. Level-three children showed considerable learning (level-three children: $M=.65, S D=.18$ vs. level-two children: $M=.41, S D=.13$ ) on the 592 characters. Likewise, using the .6 cut-off, the level-three children showed basic mastery on 392 of these characters. That is, they showed mastery on $66 \%$ of the characters not mastered by level-two children. Therefore, the total number of characters mastered by level-three school children is 2157 , or $91 \%$ of the 2357 characters. This shows a learning increment of about 17\% over level-two school children. Indicated in Figure 3, level-three school children had a mean of $75(S D=.09)$ on their 392 basic mastery characters. Consequently, 200 non-mastery level-three character items (i.e. those below the .6 cut-off) were left. The list of the 392 level-three basic mastery characters is shown in appendix 3 .

\section{Insert Figure 3 about here}

\subsubsection{Level-three Non-Mastery Characters}

200 Chinese characters $(M=.44, S D=.12)$ were found not to have been mastered by level-three school children. The list of the 200 non-mastery level-three characters is shown in appendix 4. Examination of these 200 non-mastery level-three characters reveals that many are typical of Chinese characters not learned until key stage two (i.e. levels-four to-six). Moreover, five items of the 200 Chinese characters, namely, 嶅 'centimeter', 夰 'kiss', 輀 'soft', 畧 'brief' and 巒'mountain range', were found to be particularly difficult for the level-three school children. These five characters were recognized only by between $4 \%$ and $15 \%$ of level-three school children.

\subsection{Percentage of learning in Chinese character recognition from one level to the next}

It can be observed in Figure 4 that the most rapid learning of Chinese characters occurred at level-two where the learning increment was $34 \%$ (the grey area in the stacked bar of level-two) more than level-one. The learning increment at level-three was just over half that at $17 \%$ (the grey area in the stacked bar of level-three). Thus, by 
level-three, the school children basically mastered all the Chinese characters for key stage one (levels-one to-three) in the Revised Chinese Character List (2007). This provides strong evidence that the school children's character knowledge is found to increase as they gain more education experience. Nevertheless, around $9 \%$ of the Chinese characters in the said List may still not be recognized at level-three.

Insert Figure 4 about here

\section{Discussion}

Based on the data, achieving the purpose of the study about investigating Hong Kong elementary school children's Chinese character recognition knowledge with respect to the Revised Chinese Character List (2007) and classifying the Chinese characters for key stage one in the said List into grade levels according to the school children's recognition knowledge is possible.

Firstly, the results of the study have yielded a description of Chinese character knowledge acquisition among Hong Kong Cantonese-speaking early elementary school children. Their character knowledge is found to increase with progressing educational levels. This supports the literature that school children's recognition of Chinese characters becomes greater as they progress through increasing academic levels. The acquisition during the period of level-two is rapid and marked. By level-three, the school children's ability would reach $91 \%$ coverage of the Chinese characters in the Revised Chinese Character List (2007).

The findings have important implications for Chinese character knowledge development and assessment, as well as Hong Kong language education. The Hong Kong teachers need to be aware of the school children's Chinese character knowledge development and assist the school children to develop themselves according to the level each of the school children is at. The school children's Chinese character knowledge can be accounted for by a number of factors, namely, the selection and use of the Chinese characters in a textbook, the systematic way character competence is developed in each of the children and the school children's motivation, drive and efforts in character learning. The critical conditions for character development are encounter and use. The curriculum planners and the teachers should give due consideration to the selection and the teaching of the characters the school children encounter in their particular grade level. This provides an important avenue for the school children to formulate receptive knowledge. Further, the school children should be well motivated to learn the set of Chinese characters that corresponds to their grade level. Thus, their character knowledge can be elevated to the productive level.

Secondly, 2357 Chinese characters for key stage one in the Revised Chinese Character List (2007) are classified into three proposed level lists of mastery of Chinese characters in this study. The three level lists can serve as the reference for the curriculum writers and teachers, who could draw the classified Chinese characters from the respective level lists to enhance the preparation of curriculum materials and the construction of language assessment. It is the first attempt to propose a prescriptive reference by grade level for character learning since the original Hong Kong Chinese Character Level Lists (1990). The 1184 Chinese characters for key stage two in the Revised Chinese Character List (2007) to be classified into three level lists for the Hong Kong level four, level five and level six school children are worth considering in future research. Thus, it would possibly establish six basic mastery character lists for the learning and teaching of Chinese characters for Hong Kong elementary education.

Thirdly, there appears to be no pressing need upon the key stage one (i.e. levels-one to -three) school children to acquire the set of the 200 non-mastery level-three Chinese characters. Nonetheless, the school children would gradually master them in key stage two (i.e. levels-four to -six). Examination of the 200 Chinese characters reveals many of these characters are complex characters consisting of complicated interwoven strokes, for instance, 懸 'to hang', 嘯 'to roar', 繁 'to stop', 攜 'to carry', 紮 'to tie together', 鼎 'three-legged bronze caldron', 薩 'Buddha', 囊'bag', 橲 'table' and 灎 'colorful'. A series of studies suggests that orthographic processing is the basic processing component in reading Chinese (Peng, Li, \& Yang, 1997; Shu \& Anderson, 1999; Taft, Zhu \& Peng, 1999). Furthermore, current models of Chinese reading emphasize the importance of the recognition of orthographic representation prior to the activation of phonological and meaning information in reading Chinese (Perfetti, Liu \& Tan, 2005; Taft et al., 1999). Therefore, the complication of the interwoven strokes to form the square-shape Chinese character may contribute significantly to the difficulty in recognizing them by key stage one school children. However, the key stage one school children with desirable progression to key stage two, that is to say, with increment in Chinese characters and vocabularies, with gradual development in cognition, will improve their understanding of the interwoven strokes of the Chinese characters as well as their ability to perceive and manipulate them. 
Lastly, there are five most difficult items, namely, 鳌 'centimeter', 脗 'kiss', 轒 'soft', 畧 'brief' and 巒 'mountain range ', for the key stage one school children in the list of the 200 non-mastery level-three Chinese characters. These five Chinese characters are discussed below.

The Chinese character 嶅 'centimeter', recognized by only $4 \%$ of the level-three school children, consists of a simplified form 厘 'centimeter' which earned 94\% recognition from level-two school children and is classified in the level-two basic mastery character list. The simplified form 厘 'centimeter' as in the word 厘米 'centimeter transliteration' is always used in arithmetic learning in level-two. The rare usage of the form 嶅 'centimeter' in learning arithmetic is a possible reason that 嶅 'centimeter' obtains a surprisingly low recognition among the key stage one children. Only when the school children to be promoted to key stage two and learn the Chinese four-character fixed expression 恭賀春虐 ‘Happy New Year', will the form 嶅 plausibly yield a higher recognition percentage. However, the character 嶅 means 'happiness' in this expression.

The three Chinese characters 炤 'kiss', 輀 'soft 'and 畧 'brief' obtain 8\%,13\% and 14\% recognition from the key stage one school children respectively. They are a variant form of the Chinese characters 吻 'kiss', 軟 'soft' and 略 'brief'. Interestingly, the standard forms 吻 'kiss', 軟 'soft' and 略 ' brief' appear to gain a substantial amount of recognition from the key stage one children. 吻 'kiss' (recognition 67\%) and 軟 'soft' (recognition 87\%) are classified in the level-two basic mastery character list whereas 略 'brief' (recognition 65\%) is in the level-three basic mastery list. It would be possible that the school children start to learn the standard forms 吻 'kiss', 軟 'soft' and 略 'brief' in school. Their variant form is consciously avoided from appearing in the school textbooks because in Hong Kong the norm of standard language is strictly observed in school. As a result, the key stage one school children are unable to acquire an awareness of the existence of the variant forms 脗 'kiss', 輀 'soft' and 畧 'brief'. This accounts for the strikingly low recognition of them among the Hong Kong elementary school children. Nevertheless, our findings reveal that more than $60 \%$ of the key stage one school children recognized the standard forms 吻 'kiss', 軟 'soft' and 略 'brief'. Therefore, the poor recognition of their variant form is not significant in the Hong Kong school children's Chinese character acquisition.

The Chinese character 巒 'mountain range', only recognized by 15\% of the level-three school children, contains twenty-two strokes. While most Chinese characters fall within the range of seven to seventeen strokes (Kratochvíl, 1968), the great number of strokes 巒 'mountain range' probably poses a heavier burden on the school children for recognition and makes such matters as memorization a very difficult affair.

\section{Conclusion}

In summary, the study adds new information to the literature. The results suggest that Hong Kong elementary school children's Chinese character recognition knowledge increases with progressing educational levels. Their Chinese character recognition knowledge accelerates and develops rapidly at level-two. By completion of the key stage one, the school children have a grasp of $91 \%$ coverage of the Chinese characters in the Revised Chinese Character List (2007). Further, the results generate four proposed Chinese character level lists (see Appendices 1 to 4) which are beneficial references for language education.

\section{Acknowledgments}

This study was supported by the President Development Fund of the Hong Kong Institute of Education. The author is grateful for the contribution and the co-operation of the participating schools.

\section{References}

Anderson, R. C., \& Freebody, P. (1981). Vocabulary knowledge. In J. T. Guthrie (Ed.), Comprehension and teaching: research reviews (pp. 77-117). E: International Reading Association.

Carey, S. (1978). The child as word learner. In M. Halle, J. Bresnan, \& G. Miller (Eds.), Linguistics theory and psychological reality (pp. 264-293). Cambridge, MA: MIT Press.

Chall, J. S. (1987). Two vocabulary for reading: recognition and meaning. In M. G. McKeown, \& M. E. Curtis (Eds.), The nature of vocabulary acquisition (pp. 7-17). Hilldale, NJ: Erlbaum.

Cheung, E. Y. M. (2007). Literacy knowledge of key stage one primary pupils in Hong Kong. Journal of College of Chinese Language and Culture of Jinan University, 27, 49-54.

Education and Manpower Bureau. (2005). The new academic structure for senior secondary education and higher education - action plan for investing in the future of Hong Kong. Hong Kong: Hong Kong Government, (Chapter $3)$. 
Gleason, J. B., \& Ely R. (2002). Gender differences in language development. In A. McGillicuddy-De Lisi, \& R. De Lisi (Eds.), Biology, society, and behaviour: The development of sex differences in cognition (pp. 127-154). London: Ablex Publishing.

Guojia Yuyan Wenzi Gongzuo Weiyuanhui (State Language Work Committee). (2006). Neidi Tongyong Ciyubiao (The commonly used word list). China: State Language Work Committee.

Hong Kong Curriculum Development Unit. (1990). Character list. In Syllabus for Chinese language (elementary level) (pp.69-76). Hong Kong: Education Department.

Hong Kong Curriculum Development Unit. (1996). Vocabulary list. Hong Kong: Education Department.

Hong Kong Curriculum Development Council. (2001). Learning to learn - the way forward in curriculum development. Hong Kong: Education Department, (Chapter 2).

Hong Kong Curriculum Development Unit. (2007). Vocabulary and character lists for Hong Kong primary education. Hong Kong: Education and Manpower Bureau, (Chapters 2 and 3).

Hong Kong Polytechnic University. (2003). The commonly used word corpus. Hong Kong: Hong Kong Polytechnic University.

Ke, H. W., \& Wu, R. (1987). The study of high-frequency Chinese characters and difficult Chinese characters for Taiwan level three pupils. Taipei: Taiwan National School Teacher Research Association, (Chapter 2).

Ke, H. W., \& Wu, R. (1990). The study of high-frequency Chinese characters and difficult Chinese characters for Taiwan level six pupils. Taipei: Taiwan National School Teacher Research Association, (Chapter 4).

Ke, H. W., \& Wu, R. (1993). The study of high-frequency Chinese characters and difficult Chinese characters for Taiwan junior elementary pupils. Taipei: Taiwan National School Teacher Research Association, (Chapter 2).

Kratochvíl, P. (1968). The Chinese language today. London: Hutchinson, (Chapter 5).

Li, H. (1999). The development and the preliminary examination of the preschool and primary Chinese literacy scale. Psychological Development and Education, 3, 18-24.

Li, H., Peng, H., \& Shu, H. (2006). A study on the emergence and development of Chinese orthographic awareness in preschool and school children. Psychological Development and Education, 1, 35-38.

Miller, G. A. (1988). The challenge of universal literacy. Science, 241, 1293-1299.

Ministry of Education (1998). Taiwan Jiaoyubu Changyong Ciyubiao 1998 (The commonly used word list 1998). Taiwan: Ministry of Education.

Nagy, W. E., \& Anderson, R. C. (1984). How many words are there in printed school English? Reading Research Quarterly, 19, 304-330.

Nagy, W. E., \& Herman, P. A. (1987). Breath \& depth of vocabulary knowledge: Implications for acquisition and instruction. In M. G. McKeown \& M. E. Curtis (Eds.), The nature of vocabulary acquisition (pp. 19-35). Hillsdale. NJ: Erlbaum.

Nation, I. S. P. (1990). Teaching and learning vocabulary. Boston, MA: Heinle \& Heinle, (Chapter 3).

Paribakht, T. S. \& Wesche, M. (1996). Enhancing vocabulary acquisition through reading: A hierarchy of text-related exercise types. The Canadian Modern Language Review, 52, 155-178.

Peng, D., Li, Y. P., \& Yang, H. (1997). Orthographic processing in the identification of Chinese characters. In H. C. Chen (Ed.), Cognitive processing of Chinese and related Asian languages (pp.86-108). Hong Kong: Chinese University Press.

Perfetti, C. A., Liu, Y., \& Tan, L. H. (2005). The lexical constituency model: some implications of research on Chinese for general theories of reading. Psychological Review, 112, 43-59.

Sampson, G. (1985). Writing systems: a linguistic introduction. London: Hutchinson, (Chapter 8).

Senechal, M. (1997). The differential effect of storybook reading on preschoolers' acquisition of expressive and receptive vocabulary. Journal of Child Language, 24, 123-138.

Shu, H., \& Anderson, R. C. (1999). Learning to read Chinese: The development of metalinguistic awareness. In J. Wang, A. W. Inhoff, \& H. C. Chen (Eds.), Reading Chinese script: A cognitive analysis (pp. 1-18). Mahwah, NJ: Erlbaum.

SPSS, Inc. (2008). SPSS for Windows, release 17. Chicago, IL: SPSS, Inc.

Stanovich, K. E. (1986). Matthew effects in reading: some consequences of individual differences in the acquisition of literacy. Reading Research Quarterly, 21, 360-407. 
Taft, M., Zhu, X., \& Peng, D. (1999). Positional specificity of radicals in Chinese character recognition. Journal of Memory and Language, 40, 498-519.

Terman, L. M. (1916). The measurement of intelligence. New York: Houghton Mifflin, (Chapters 1 and 7).

Tse, S. K., Marton, F., Ki, W. W., \& Loh, E. K. Y. (2007). An integrative perceptual approach for teaching Chinese characters. Instructional Science, 35 (5), 375-406.

Wechsler, D. (1949). Manual for the Wechsler intelligence scale for children. New York: Psychological Corporation, (Chapter 1).

\section{Appendix 1}

The 963 Level-one Basic Mastery Characters, Ordered from 1 Stroke to 25 Strokes

\begin{tabular}{|c|c|c|c|c|c|c|c|c|c|c|c|c|c|c|c|}
\hline 1 stroke & 乙 & $\cdots$ & & & & & & & & & & & & & \\
\hline 2 strokes & $T$ & $t$ & $\lambda$ & 人 & 力 & 又 & 九 & \} & $=$ & $\lambda$ & + & $\pi$ & & & \\
\hline \multirow[t]{2}{*}{3 strokes } & + & $\tau$ & 丈 & 又 & 丸 & e & 巾 & + & \pm & 山 & 己 & $子$ & 女 & $I$ & $F$ \\
\hline & $\square$ & \pm & 大 & 小 & $\equiv$ & 上 & 才 & 也 & & & & & & & \\
\hline \multirow[t]{4}{*}{4 strokes } & tn & 止 & 爪 & 反 & 比 & $\pi$ & 及 & 升 & 冈 & R & 犬 & 化 & 什 & 众 & 支 \\
\hline & $z$ & 井 & 片 & 元 & 今 & 分 & 文 & 万 & 不 & 木 & 友 & 毛 & 巴 & 牙 & 六 \\
\hline & 王 & 日 & 午 & 月 & 中 & 天 & 五 & 水 & 太 & $火$ & $\leadsto$ & 少 & 父 & 牛 & $心$ \\
\hline & 公 & 手 & 夫 & & & & & & & & & & & & \\
\hline \multirow[t]{4}{*}{5 strokes } & $E$ & 代 & 共 & 平 & 乎 & 未 & 冊 & 只 & 布 & 仔 & 立 & 永 & 它 & 仙沶 & 卡 \\
\hline & 白 & 央 & 以 & 台 & 由 & 纤 & 市 & 功 & 汁 & 北 & 甲 & 世 & 皮 & 兄 & 册 \\
\hline & 支 & 古 & 半 & 司 & 目 & 奶 & 本 & 可 & 石 & 冬 & 让 & $\neq$ & 用 & 他 & 去 \\
\hline & 마 & 本 & 出 & 母 & 四 & 瓜 & 生 & $\theta$ & 코 & 打 & 加 & 包 & 外 & 北 & \\
\hline \multirow[t]{5}{*}{6 strokes } & 乒 & 此 & In & 吐 & 守 & 州 & 年 & 任 & 向 & 印 & 危 & 死 & 乓 & 伍 & 羽 \\
\hline & 休 & 江. & 朱 & 池 & 因 & 考 & 吉 & 件 & 至 & 冰 & 次 & 宇 & 尖 & 共 & 行 \\
\hline & 曲 & 如 & 各 & 百 & 收 & 再 & 忙 & 安 & 合 & 全 & 地 & 灰 & 米 & 羊 & 老 \\
\hline & 早 & 有 & 肉 & 舌 & 闹 & 光 & 她 & 衣 & 西 & 先 & 在 & 多 & 耳 & 自 & 字 \\
\hline & 交 & 㕿 & 色 & 吃 & 回 & 好 & 朵 & 任 & $\varepsilon_{0}$ & 成 & & & & & \\
\hline \multirow[t]{5}{*}{7 strokes } & 品 & 伸 & 否 & 初 & 冷 & 志 & 抓 & 村 & 助 & 床 & 串 & 吵 & 身 & 忘 & 但 \\
\hline & 低 & 努 & 汪 & 足 & 位 & 伴 & 找 & 形 & 良 & 兵 & 呀 & 克 & 住 & 那 & 吧 \\
\hline & 吹 & 孝 & 別 & 肚 & 伯 & 低 & 何 & 给 & 貝 & 吱 & 李 & 完 & 호 & 步 & 妙 \\
\hline & 没 & 尾 & 没 & 走 & 每 & 牠 & 汽 & 里 & 兒 & $\overline{1}$ & 作 & 快 & 你 & 沙 & 告 \\
\hline & 角 & 把 & 希 & 事 & 弟 & 男 & 坐 & 我 & 求 & & & & & & \\
\hline \multirow[t]{7}{*}{8 strokes } & 典 & 周 & 依 & 注 & 性 & 京 & 泥 & 使 & 近 & 帕 & 往 & 坡 & 爭 & 率 & 底 \\
\hline & 命 & 板 & 夜 & 炒 & 招 & 易 & 官 & 苂 & 非 & 拉 & 呢 & 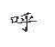 & 怪 & 落 & 姑 \\
\hline & 抱 & 肥 & 波 & 欣 & 朋 & 定 & 垃 & 所 & 免 & 泡 & 淞 & 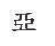 & 卷 & 育 & 旺 \\
\hline & 很 & 姓 & 我 & 其 & 夺 & 法 & 李 & 杯 & 刷 & 店 & 阿 & 服 & 侃 & 房 & 叔 \\
\hline & 味 & 拍 & 知 & 怕 & 東 & 放 & 油 & 枝 & 直 & 兩 & 具 & 青 & 泳 & $\mathrm{x} / \mathrm{C}$ & 林 \\
\hline & 空 & 昆 & 姐 & 物 & 来 & 洺 & 朋 & 果 & 的 & 笆 & 雨 & 妹 & 牧 & 明 & 花 \\
\hline & 和 & 事 & 金 & $p$ & 長 & 到 & 者 & 表 & 虎 & 兔 & 兒 & & & & \\
\hline \multirow[t]{5}{*}{9 strokes } & 唒 & 勇 & 施 & 拜 & 者 & 巷 & 茄 & 指 & 冠 & 律 & 便 & 훔 & 洞 & 怎 & 背 \\
\hline & 虹 & 泉 & 苦 & 建 & 柏 & 咥 & 珍 & 紀 & 姨 & 皇 & 城 & 南 & 恰 & 頁 & 胖 \\
\hline & 重 & 拾 & 屋 & 品 & 耍 & 界 & 昨 & 保 & 科 & 面 & 甚 & 活 & 苗 & 娃 & 思 \\
\hline & 為 & 哈 & 食 & 故 & 洋 & 要 & 信 & 春 & 室 & 穿 & 很 & 紅 & 香 & 核 & 秋 \\
\hline & 看 & 音 & 前 & 後 & 風 & 莪 & 是 & 美 & 厚 & 英 & 祝 & 神 & 洗 & 食 & \\
\hline \multirow[t]{4}{*}{10 strokes } & 哂 & 財 & 借 & 紛 & 值 & 哦 & 候 & 益 & 容 & 烟 & 骨 & 恭 & 原 & 载 & 酒 \\
\hline & 鬼 & 捉 & 留 & 间 & 院 & 乘 & 唐 & 哪 & 害 & 娘 & 旅 & 迷 & 哥 & 消 & 拿 \\
\hline & 庭 & 害 & 送 & 粉 & 座 & 浪 & 員 & 級 & 珠 & 站 & 倒 & 病 & 記 & 桌 & 狼 \\
\hline & 思 & 夏 & 能 & 倍 & 退 & 茶 & 息 & 烏 & 班 & 紙 & 哭 & 時 & 書 & 高 & 起 \\
\hline
\end{tabular}




\begin{tabular}{|c|c|c|c|c|c|c|c|c|c|c|c|c|c|c|c|}
\hline \multirow{4}{*}{11 strokes } & 扇 & 個 & 草 & 隻 & 真 & 島 & 們 & 師 & 氧 & 笑 & 海 & 馬 & 家 & 校 & 朗 \\
\hline & 梯 & 痳 & 够 & 聆 & 部 & 終 & 淨 & 排 & 啡 & 瓶 & 細 & 稀 & 票 & 涼 & 鹿 \\
\hline & 晨 & 現 & 深 & 夠 & 教 & 密 & 盒 & 理 & 許 & 救 & 乾 & 强 & 從 & 視 & 笨 \\
\hline & 啦 & 粒 & 健 & 猜 & 組 & 偉 & 參 & 蛇 & 剪 & 康 & 通 & 強 & 假 & 圈 & 區 \\
\hline \multirow{7}{*}{12 strokes } & 情 & 望 & 梨 & 婆 & 堂 & 停 & 教 & 甜 & 啊 & 啤 & 您 & 彩 & 條 & 蛋 & 雪 \\
\hline & 鳥 & 國 & 眼 & 甜 & 常 & 晚 & 張 & 球 & 唱 & 脚 & 動 & 做 & 魚 & 帶 & 處 \\
\hline & 都 & 清 & 船 & 得 & 第 & 這 & 雪 & & & & & & & & \\
\hline & 圍 & 勝 & 掌 & 帽 & 廁 & 喔 & 棵 & 痛 & 結 & 着 & 植 & 帽 & 菇 & 椅 & 欺 \\
\hline & 尊 & 貼 & 登 & 週 & 蛛 & 補 & 寒 & 量 & 景 & 無 & 勞 & 鄉 & 湖 & 傘 & 曾 \\
\hline & 評 & 湯 & 街 & 晶 & 訴 & 幾 & 順 & 䄸 & 就 & 棋 & 超 & 提 & 報 & 等 & 進 \\
\hline & 隊 & 然 & 放 & 㘍 & 温 & 琴 & 蛙 & 答 & 間 & 猴 & 琴 & 斑 & 集 & 渴 & 給 \\
\hline \multirow{7}{*}{13 strokes } & 普 & 華 & 詞 & 森 & 最 & 發 & 菜 & 短 & 雲 & 跑 & 期 & 最 & 港 & 單 & 開 \\
\hline & 游 & 都 & 筆 & 陽 & 畫 & 富 & 飲 & 紫 & 喝 & 黄 & 智 & 象 & 場 & 買 & 晴 \\
\hline & 飯 & 鸱 & & & & & & & & & & & & & \\
\hline & 暗 & 勤 & 筷 & 達 & 葡 & 電 & 塊 & 詩 & 傷 & 俨 & 舅 & 義 & 睬 & 敬 & 娗 \\
\hline & 準 & 塘 & 蜂 & 滑 & 暖 & 意 & 敬 & 零 & 煙 & 落 & 緸 & 業 & 跟 & 矮 & 運 \\
\hline & 萬 & 雷 & 當 & 禓 & 歲 & 農 & 想 & 鉛 & 道 & 路 & 腦 & 跳 & 話 & 葉 & 頓 \\
\hline & 照 & 溫 & 睛 & 焀 & 過 & 聖 & 裹 & 新 & 會 & 愛 & 爺 & 園 & 媽 & 嗎 & 飽 \\
\hline \multirow{4}{*}{14 strokes } & 與 & 號 & 福 & 遊 & 鼠 & 節 & 獅 & 圓 & & & & & & & \\
\hline & 圖 & 趕 & 領 & 貌 & 銀 & 瑰 & 綿 & 漂 & 算 & 演 & 䡕 & 精 & 察 & 碟 & 説 \\
\hline & 齊 & 慢 & 嘉 & 種 & 遠 & 裹 & 夢 & 慢 & 對 & 語 & 熊 & 蜜 & 綠 & 舞 & 麼 \\
\hline & 說 & 滿 & 像 & 歌 & 鼻 & 夢 & 瘦 & 餅 & 睡 & 署 & & & & & \\
\hline \multirow[t]{3}{*}{15 strokes } & 廣 & 儀 & 碼 & 閲 & 獎 & 養 & 閱 & 跤 & 澆 & 蝦 & 瘦 & 養 & 彈 & 踏 & 轌 \\
\hline & 踢 & 輪 & 髮 & 箖 & 熱 & 鞋 & 駝 & 歯 & 影 & 蝴 & 樣 & 趣 & 線 & 誰 & 樓 \\
\hline & 潔 & 蝶 & 課 & 樂 & 餓 & 誕 & 豬 & 數 & 請 & 窵 & & & & & \\
\hline \multirow[t]{3}{*}{16 strokes } & 擋 & 錯 & 戰 & 燈 & 錢 & 橋 & 器 & 錄 & 隧 & 橡 & 螞 & 燒 & 糖 & 機 & 默 \\
\hline & 藮 & 鴨 & 餐 & 糕 & 機 & 猪 & 橙 & 澡 & 親 & 頭 & 操 & 静 & 樹 & 貓 & 學 \\
\hline & 整 & 興 & 館 & 龍 & 嘴 & & & & & & & & & & \\
\hline \multirow[t]{2}{*}{17 strokes } & 醜 & 鍋 & 顆 & 㮩 & 營 & 講 & 瞬 & 環 & 賽 & 脸 & 謝 & 還 & 墨 & 鮮 & 聲 \\
\hline & 戲 & 幫 & 薯 & 禮 & & & & & & & & & & & \\
\hline 18 strokes & 檄 & 題 & 鵝 & 顔 & 醫 & 藍 & 蟲 & 雙 & 鼅 & & & & & & \\
\hline \multirow[t]{2}{*}{19 strokes } & 藝 & 鏡 & 邊 & 簿 & 證 & 羅 & 難 & 寵 & 關 & 薬 & 簽 & 麗 & 麗 & 麗 & 識 \\
\hline & 離 & & & & & & & & & & & & & & \\
\hline 20 strokes & 鐘 & 覺 & 整 & 寶 & 籃 & 騮 & 警 & 蘋 & & & & & & & \\
\hline 21 strokes & 護 & 蘭 & 鐵 & 魔 & 麵 & 護 & & & & & & & & & \\
\hline 22 strokes & 灘 & 奜 & 讀 & 讀 & 彎 & 㯖 & 歡 & 歡 & & & & & & & \\
\hline 23 strokes & 晍 & 蘿 & 體 & 變 & & & & & & & & & & & \\
\hline 24 strokes & 赦 & 讓 & & & & & & & & & & & & & \\
\hline 25 strokes & 灣 & & & & & & & & & & & & & & \\
\hline
\end{tabular}




\section{Appendix 2}

\section{The 802 Level-two Basic Mastery Characters, Ordered from 3 Strokes to 27 Strokes}

\begin{tabular}{|c|c|c|c|c|c|c|c|c|c|c|c|c|c|c|c|}
\hline 3 strokes & 凡 & 久 & & & & & & & & & & & & & \\
\hline 4 strokes & 13 & 표 & $F$ & 斤 & 介 & 孔 & 引 & 互 & & & & & & & \\
\hline 5 strokes & 令 & 旦 & 犯 & 且 & 男 & $甘$ & 付 & 示 & 令 & 丙 & 民 & 充 & 巧 & 必 & \\
\hline \multirow[t]{2}{*}{6 strokes } & 讵 & 仿 & 扣 & 王 & 划 & 名 & 舟 & 至 & 此 & 离 & 汗 & 而 & 企 & 列 & 式 \\
\hline & 存 & 冲 & 竹 & 并 & & & & & & & & & & & \\
\hline \multirow[t]{4}{*}{7 strokes } & 佈 & 均 & 址 & 谷 & 序 & 辰 & 邨 & 沉 & 吹 & 投 & 吻 & 我 & 私 & 即 & \\
\hline & 吞 & 扶 & 似 & 秀 & 束 & 巫 & 狂 & 妖 & 卵 & 災 & 夾 & 却 & 屁 & 吩 & \\
\hline & 社 & 抄 & 困 & 羙 & 扮 & 辛 & 材 & 圾 & 忍 & 冲 & 利 & 防 & 估 & 更 & \\
\hline & 芒 & 洪 & 吸 & 改 & 尿 & 否 & 壯 & & & & & & & & \\
\hline \multirow[t]{5}{*}{8 strokes } & 府 & 卦 & 忠 & 附 & 拘 & 刺 & 抵 & 芭 & 肩 & 尚 & 拆 & 刮 & 孤 & 泊 & 氛 \\
\hline & 制 & 抵 & 刻 & 券 & 拋 & 岸 & 昏 & 佩 & 玫 & 妻 & 咐 & 宜 & 股 & & \\
\hline & 奔 & 沿 & 忽 & 抽 & 泣 & 咏 & 武 & 肯 & 披 & 拔 & 抬 & 呵 & 咖 & 並 & \\
\hline & 狐 & 版 & 取 & 供 & 拖 & 芝 & 於 & 返 & 居 & 狀 & 治 & 例 & 或 & 幸 & \\
\hline & 佳 & 毒 & 於 & 受 & 始 & 念 & 芬 & 第 & 抹 & 迎 & 些 & 底 & 念 & 些 & 延 \\
\hline \multirow[t]{6}{*}{9 strokes } & 俗 & 挖 & 怒 & 省 & 亮 & 係 & 若 & 揙 & 柳 & 缸 & 屎 & 疮 & 峌 & 恨 & 待 \\
\hline & 珊 & 挑 & 祖 & 酒 & 陌 & 染 & 胃 & 咳 & 秒 & 岸 & 急 & 威 & 柔 & 津 & 楛 \\
\hline & 降 & 枯 & 冒 & 狠 & 首 & 段 & 突 & 負 & 柜 & 型 & 柴 & 洲 & 胡 & 限 & 郊 \\
\hline & 封 & 查 & 柱 & 卻 & 架 & 盆 & 拼 & 帥 & 陝 & 訂 & 持 & & & & \\
\hline & 胎 & 帝 & 派 & 按 & 玻 & 珊 & 約 & 咬 & 炮 & 冒 & 郎 & 度 & 急 & 流 & 厘 \\
\hline & 咪 & 炸 & 計 & 客 & 祕 & & & & & & & & & & \\
\hline \multirow[t]{5}{*}{10 strokes } & 浸 & 悄 & 唉 & 紋 & 峰 & 浴 & 浮 & 埋 & 症 & 訓 & 准 & 配 & 拳 & 悅 & 脆 \\
\hline & 倦 & 霄 & 烈 & 般 & 恐 & 租 & 疼 & 悔 & 疲 & 捕 & 效 & 展 & 倉 & & \\
\hline & 涕 & 悦 & 桔 & 孫 & 桃 & 射 & 眠 & 倉 & 烤 & 除 & 宮 & 翁 & 唋 & 料 & 特 \\
\hline & 討 & 弱 & 豹 & 徒 & 陣 & 案 & 翅 & 鬥 & 蚊 & 套 & 追 & 根 & 修 & 逃 & 格 \\
\hline & 差 & 㓮 & 破 & 旁 & 針 & 浸 & 祥 & 柴 & 殺 & & & & & & \\
\hline \multirow[t]{7}{*}{11 strokes } & 袋 & 側 & 毫 & 鼓 & 捧 & 販 & 竟 & 探 & 啟 & 猛 & 吗 & 巢 & 莊 & 偶 & 啤 \\
\hline & 脫 & 捨 & 毫 & 紹 & 液 & 聆 & 梳 & 掙 & 陰 & 浅 & 眾 & 淇 & 婦 & 堅 & 毒 \\
\hline & 陰 & 逗 & 啪 & 掃 & 敗 & 寄 & 培 & 吟 & 產 & 脱 & 堆 & 貨 & 淋 & 蛀 & 副 \\
\hline & 累 & 訪 & 來 & 笛 & 貪 & 焗 & 粗 & 章 & 桶 & 術 & 問 & 基 & 掛 & 殺 & 畢 \\
\hline & 荷 & 採 & 設 & 婚 & 滨 & 厓 & 商 & 敏 & 推 & 規 & 責 & 貪 & 麥 & 接 & 豚 \\
\hline & 雀 & 梅 & 軟 & 連 & 專 & 釣 & 掉 & 惜 & 薪 & 陪 & 售 & 野 & 頂 & 造 & 偷 \\
\hline & 厠 & 務 & 將 & 被 & 掃 & 盛 & & & & & & & & & \\
\hline \multirow[t]{6}{*}{12 strokes } & 款 & 裕 & 棖 & 壼 & 傍 & 廂 & 階 & 盗 & 毯 & 喂 & 喚 & 辚 & 尋 & 渡 & 棕 \\
\hline & 絲 & 悲 & 喉 & 哟 & 閒 & 喊 & 棒 & 鈎 & 款 & 琶 & 栗 & 斯 & 項 & 創 & 黑 \\
\hline & 萄 & 㥢 & 喱 & 厦 & 詠 & 廊 & 散 & 堡 & 悶 & 番 & 診 & 著 & 巷 & 握 & 硬 \\
\hline & 替 & 揚 & 幅 & 減 & 菲 & 牌 & 愉 & 備 & 裙 & 測 & 菌 & 程 & 換 & 菠 & 貴 \\
\hline & 暑 & 復 & 筒 & 惡 & 敢 & 揮 & 賀 & 畕 & 跌 & 善 & 費 & 窗 & 粥 & 創 & 搜 \\
\hline & 透 & 郵 & 菊 & & & & & & & & & & & & \\
\hline
\end{tabular}




\begin{tabular}{|c|c|c|c|c|c|c|c|c|c|c|c|c|c|c|c|}
\hline \multirow[t]{4}{*}{13 strokes } & 恽 & 逼 & 愧 & 腫 & 塔 & 碌 & 隇 & 損 & 賊 & 艇 & 塗 & 嗡 & 搜 & 公頁 & 預 \\
\hline & 搞 & 煲 & 廈 & 搶 & 椰 & 較 & 署 & 梳 & 煩 & 搭 & 搶 & 幹 & 該 & 遇 & 源 \\
\hline & 頑 & 填 & 熖 & 傳 & 零 & 腰 & 腸 & 遍 & 罪 & 楚 & 鼓 & 躲 & 碗 & 搖 & 鈴 \\
\hline & 誠 & 裡 & 解 & 載 & 極 & 搬 & 試 & 感 & 微 & 飼 & 著 & 碰 & 暑 & 惹 & \\
\hline \multirow[t]{4}{*}{14 strokes } & 寞 & 等 & 管 & 膏 & 誌 & 劃 & 誦 & 蓋 & 賓 & 聚 & 複 & 知司 & 構 & 尌 & 熞 \\
\hline & 製 & 漁 & 領 & 腐 & 誤 & 福 & 慣 & 盡 & 厭 & 逢 & 態 & 酸 & 睘 & 旗 & 槍 \\
\hline & 蜘 & 聞 & 浓 & 漢 & 榮 & 維 & 粽 & 端 & 實 & 網 & 境 & 㮽 & 漫 & 需 & 摘 \\
\hline & 窩 & 團 & 蜻 & 認 & 緊 & 滴 & 腿 & 管 & 漫 & 愿 & 槍 & & & & \\
\hline \multirow[t]{5}{*}{15 strokes } & 身尚 & 盘 & 墨 & 蝠 & 駕 & 煟 & 焤 & 駅 & 輩 & 摩 & 調 & 獎 & 層 & 者 & 嘖 \\
\hline & 熟 & 暫 & 敨 & 啎 & 劇! & 諒 & 增 & 編 & 撞 & 糊 & 蝠 & 暴 & 磅 & 幣 & 麥正 \\
\hline & 膚 & 黎 & 袡 & 論 & 鋒 & 慧 & 擞 & 廢 & 鄰 & 嘻 & 衝 & 模 & 播 & 歐 & 閙 \\
\hline & 需 & 確 & 衛 & 踩 & 箭 & 璃 & 遮 & 標 & 價 & 衛 & 蓮 & 鹿 & 餃 & 適 & 劍 \\
\hline & 練 & 篇 & 賞 & 翏 & 德 & 府 & 䝴 & 稌 & & & & & & & \\
\hline \multirow[t]{2}{*}{16 strokes } & 壁 & 錶 & 獨 & 駡 & 激 & 横 & 撿 & 謀 & 磨 & 輸 & 兟 & 憶 & 隨 & 銅 & 選 \\
\hline & 魚 & 舉 & 辦 & 險 & 螢 & 辝 & 曉 & 鮑 & 擔 & 曆 & 毞 & 醒 & 樽 & 積 & \\
\hline \multirow[t]{2}{*}{17 strokes } & 雬力 & 篫 & 雖 & 詻 & 檢 & 霜 & 擗 & 優 & 檔 & 䝰 & 臨 & 獲 & 總 & 濕 & 聯 \\
\hline & 謎 & 跡 & 謊 & 總 & 擦 & 績 & 孆 & 聰 & 戴 & 翼 & 薄 & 應 & & & \\
\hline \multirow[t]{2}{*}{18 strokes } & 擾 & 鎮 & 藂 & 醬 & 笞 & 簡 & 眸 & 蜎 & 樌 & 職 & 緛 & 蝔 & 新 & 舊 & 離 \\
\hline & 嬸 & 事專 & 营点 & 糧 & 騎 & 鯊 & 鍫 & 藏 & & & & & & & \\
\hline \multirow[t]{2}{*}{19 strokes } & 蝘 & 雚力 & 霧 & 騙 & 繪 & 禱 & 影 & 蟹 & 臘 & 稳 & 解京 & 繩 & 懷 & 哭 & 願 \\
\hline & 蟻 & 類 & 懶 & 壤 & & & & & & & & & & & \\
\hline 20 strokes & 嚴 & 龆威 & 㗔 & 齒令 & 襪 & 裓 & 議 & 繼 & 爐 & 繁風 & 篗力 & & & & \\
\hline 21 strokes & 爛 & 嚿 & 欄 & 聮鳥 & 續 & 顧 & 瀻 & 響 & 露 & & & & & & \\
\hline 22 strokes & 攤 & 洏 & 權 & 臟感 & 灑 & 籠 & 驕 & & & & & & & & \\
\hline 23 strokes & 警 & 骿 & 曬 & 驚 & 驗 & & & & & & & & & & \\
\hline 24 strokes & 知蒦 & 鷹 & 擥 & 露 & & & & & & & & & & & \\
\hline 25 strokes & 敬睍 & 簹 & 擎見 & & & & & & & & & & & & \\
\hline 26 strokes & 讚 & & & & & & & & & & & & & & \\
\hline 27 strokes & 鑽 & & & & & & & & & & & & & & \\
\hline
\end{tabular}




\section{Appendix 3}

\section{The 392 Level-three Basic Mastery Characters, Ordered from 3 Strokes to 27 Strokes}

\begin{tabular}{|c|c|c|c|c|c|c|c|c|c|c|c|c|c|c|c|}
\hline 3 strokes & 夕 & 弓 & 气 & & & & & & & & & & & & \\
\hline 5 strokes & 判 & 采 & 圽 & 申 & 可 & 仗 & & & & & & & & & \\
\hline 6 strokes & 吋 & 托 & 伙 & 伊 & 吊 & 份 & & & & & & & & & \\
\hline \multirow[t]{2}{*}{7 strokes } & 皇 & 杆 & 批 & 刨] & 杧 & 忌 & 劫 & 抗 & 含 & 坊 & 佔 & 妝 & 盯 & 含 & 杖 \\
\hline & 究 & 判 & 吠 & 呆 & 均 & & & & & & & & & & \\
\hline \multirow[t]{2}{*}{8 strokes } & 坪 & 拐 & 常 & 阻 & 河 & 帚 & 拇 & 舍 & 怖 & 沫 & 卒 & 拌 & 押 & 枕 & 協 \\
\hline & 拒 & 采 & 侄 & 承 & 況 & 侍 & 固 & 衫 & 祈 & & & & & & \\
\hline \multirow[t]{2}{*}{9 strokes } & 映 & 砌 & 促 & 盼 & 怨 & 枱 & 姪 & 侵 & 述 & 柚 & 相 & 恒 & 砂 & 砍 & 姿 \\
\hline & 奏 & 侵 & 狡 & 則 & 眉 & 既 & 括 & 致 & 怒 & 茅 & 垂 & 政 & & & \\
\hline \multirow[t]{2}{*}{10 strokes } & 兼 & 振 & 哨 & 疾 & 宴 & 核 & 畜 & 剃 & 耕 & 賁 & 紗 & 秩 & 桑 & 眨 & 庫 \\
\hline & 索 & 狸 & 冤 & 捐 & 席 & 缺 & 湮 & 航 & 奥 & 峯 & 荊 & 袖 & 蚣 & 蒜 & 荒 \\
\hline \multirow[t]{3}{*}{11 strokes } & 速 & 捷 & 略 & 彗 & 城 & 悠 & 痕 & 祭 & 措 & 聊 & 逐 & 逢 & 陷 & 帳 & 械 \\
\hline & 偏 & 啓 & 寂 & 捲 & 匙 & 啄 & 貧 & 添 & 拰 & 途 & 移 & 控 & 淡 & 陸 & 異 \\
\hline & 堵 & 添 & & & & & & & & & & & & & \\
\hline \multirow[t]{3}{*}{12 strokes } & 琵 & 渠 & 堵 & 稍 & 甥 & 金丑 & 裁 & 啼 & 棍 & 疏 & 喇 & 掣 & 距 & 痘 & 萍 \\
\hline & 須 & 滋 & 筋 & 棚 & 惰 & 割 & 舒 & 脾 & 喜 & 裂 & 菱 & 腕 & 腔 & 割 & 喻 \\
\hline & 滋 & 童 & 剩 & 插 & 越 & 統 & 殘 & 絕 & 嫂 & 虚 & 插 & & & & \\
\hline \multirow[t]{3}{*}{13 strokes } & 傾 & 跡 & 隔 & 茂 & 滔 & 稚 & 掛 & 煤 & 猾 & 殿 & 漖 & 塑 & 詢 & 跨 & 葵 \\
\hline & 勢 & 置 & 塞 & 瑚 & 睇 & 傭 & 愚 & 詳 & 鈴 & 睦 & 痰 & 叠 & 群 & 禁 & 頒 \\
\hline & 溪 & 嫂 & 禽 & 裝 & 滗 & 碎 & 蛙 & 茲 & 慈 & & & & & & \\
\hline \multirow[t]{3}{*}{14 strokes } & 磁 & 貌里 & 漱 & 熱 & 塲 & 綵 & 摔 & 髇 & 爾 & 漠 & 摔 & 隺 & 輔 & 僕 & 裳 \\
\hline & 兼欠 & 漲 & 熄 & 榕 & 荅 & 飾 & 漏 & 幕 & 躲 & 綫 & 慚 & 惨 & 磁 & 敲 & 榜 \\
\hline & 際 & 歴 & 碧 & 嘔 & 榴 & 漸 & 疑 & 膀 & 颱 & 蓄 & 蒸 & 蒼 & 孶 & & \\
\hline \multirow[t]{3}{*}{15 strokes } & 魷 & 膝 & 隣 & 踪 & 罷 & 銳 & 㾣 & 撐 & 寬 & 瞎 & 撥 & 鋭 & 捗 & 舖 & 撕 \\
\hline & 瘡 & 廠 & 寬 & 鴉 & 靚 & 憎 & 廟 & 憂 & 憤 & 範 & 靠 & 誼 & 潑 & 稻 & 震 \\
\hline & 瞎 & 蝙 & 窮 & 艘 & 蔭 & 蔭 & 蔥 & 艘 & & & & & & & \\
\hline 16 strokes & 撻 & 燃 & 擁 & 諧 & 雕 & 磚 & 笻 & 墙 & 駱 & 樽 & 遺 & 擇 & 遵 & 舊 & \\
\hline \multirow[t]{2}{*}{17 strokes } & 鍵 & 燦 & 螺 & 䥡 & 繁 & 譬 & 蹈 & 縫 & 缩 & 壓 & 䱏 & 罴 & 燭 & 閣 & 擠 \\
\hline & 鸽 & 邀 & 牆 & 獲 & 嘡 & 新 & 儲 & & & & & & & & \\
\hline 18 strokes & 額 & 蹟 & 學 & 覆 & 歸 & 蹤 & 擲 & 檬 & 歸 & 儲 & 雜 & 擴 & & & \\
\hline 19 strokes & 嚨 & 穫 & 辭 & 贊 & 穫 & 藤 & & & & & & & & & \\
\hline 20 strokes & 耭 & 辫 & 釋 & 糯 & 籍 & 競 & 齡 & 礦 & 耀 & 饑 & & & & & \\
\hline 21 strokes & 攝 & 灌 & 覽 & 續 & 灌 & 躍 & 屬 & 䘽 & & & & & & & \\
\hline 22 strokes & 卧 & 琵 & 疊 & 灑 & 權 & & & & & & & & & & \\
\hline 23 strokes & 攪 & 顯 & & & & & & & & & & & & & \\
\hline 25 strokes & 籮 & & & & & & & & & & & & & & \\
\hline 26 strokes & 嚍 & & & & & & & & & & & & & & \\
\hline 27 strokes & 纜 & 䱾 & & & & & & & & & & & & & \\
\hline
\end{tabular}




\section{Appendix 4}

The 200 Level-three Non-mastery Characters, Ordered from 4 Strokes to 28 Strokes

\begin{tabular}{|c|c|c|c|c|c|c|c|c|c|c|c|c|c|c|c|}
\hline 4 strokes & 匀 & 兮 & 扎 & 与于 & & & & & & & & & & & \\
\hline 5 strokes & 凹 & 右 & 瓦 & 本 & & & & & & & & & & & \\
\hline 6 strokes & 禹 & 汗 & 寺 & 匠 & 宅 & 污 & & & & & & & & & \\
\hline 7 strokes & 沛 & 㭉 & 阱 & 抖 & & & & & & & & & & & \\
\hline 8 strokes & 蚟 & 泄 & 围 & 肢 & 帖 & 弧 & 谷 & 枉 & 拐 & 泛 & 祇 & & & & \\
\hline 9 strokes & 枌 & 屏 & 竿 & 唡 & 恤 & 茂 & 耐 & & & & & & & & \\
\hline \multirow[t]{2}{*}{10 strokes } & 耘 & 埕 & 㿿 & 稓 & 矩 & 羔 & 峽 & 争 & 栖 & 耻 & 倘 & 恥 & 紡 & 陛 & 框 \\
\hline & 烘 & 訅 & 狹 & 唇 & 匪 & 固 & 窄 & 秤 & 迹 & 笆 & 岀 & & & & \\
\hline 11 strokes & 沿 & 畧 & 襍 & 梘 & 唖 & 紮 & 梭 & 勒 & 掩 & 欲 & 捱 & 惦 & 淹 & 掘 & 趾 \\
\hline \multirow[t]{2}{*}{13 strokes } & 畭奇 & 鈎 & 建 & 急 & 洷 & 肆 & 毀 & 槐 & 酸 & 廉 & 捣 & 馴 & 釷 & 綁 & 馳 \\
\hline & 催 & 鼎 & & & & & & & & & & & & & \\
\hline 14 strokes & 䖝 & 畭 & 些犬 & 䰟 & 嗽 & 携 & 發 & 滲 & 軄 & 浗 & 嬯 & 蝕 & & & \\
\hline 15 strokes & 金助 & 談 & 霉 & 緻 & 毆 & 嘹 & 僻 & 慾 & 誔 & 邹友 & 潦 & 鞍 & 嘲 & 鋪 & 䜤 \\
\hline 16 strokes & 軦 & 棈 & 霓 & 注 & 鴙 & 擂 & 鍢 & 芯 & 餡 & & & & & & \\
\hline 17 strokes & 擡 & 䦚 & 蕾 & 哏 & 筫 & 嚑 & 䰷 & & & & & & & & \\
\hline 18 strokes & 蹱 & 美 & 薩 & 樹 & 㮱 & 滤 & 鞭 & 身融 & 淺 & 餝 & & & & & \\
\hline 19 strokes & 糖 & 龍 & 辫 & & & & & & & & & & & & \\
\hline 28 strokes & 整血 & & & & & & & & & & & & & & \\
\hline
\end{tabular}


Table 1. Sample Distribution

\begin{tabular}{cccc}
\hline & & \multicolumn{2}{c}{ Gender } \\
\cline { 3 - 4 } Level & $\mathrm{n}$ & Male & Female \\
\hline Level 1 & 936 & 483 & 453 \\
Level 2 & 974 & 519 & 455 \\
Level 3 & 1032 & 569 & 463 \\
Total & 2942 & 1571 & 1371 \\
\hline
\end{tabular}

Table 2. Chinese Character Recognition Performance in Level One, Level Two and Level Three on 2357 characters

\begin{tabular}{ccccc}
\hline Level & Mean & SD & Minimum & Maximum \\
\hline Level 1 & $.54 \dagger$ & .28 & .04 & 1.00 \\
Level 2 & .75 & .23 & .08 & 1.00 \\
Level 3 & .87 & .17 & .04 & 1.00 \\
\hline
\end{tabular}

$\mathrm{n}=2357$ (note: this refers to the number of the character items, not the children.)

$\dagger$ The mean indicates the proportion of character recognition.



Figure 1. Level-one Mastery Characters 


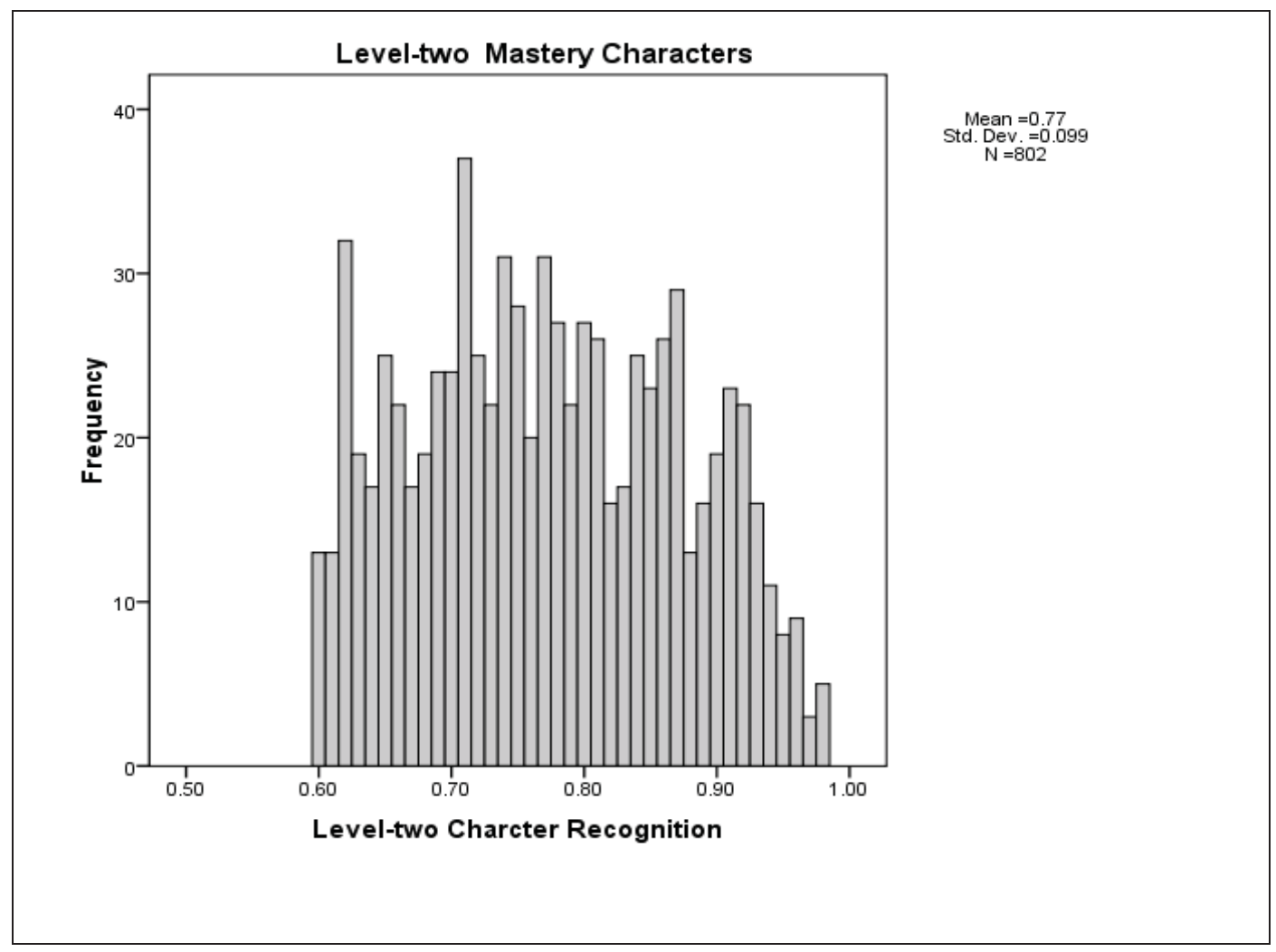

Figure 2. Level-two Mastery Characters

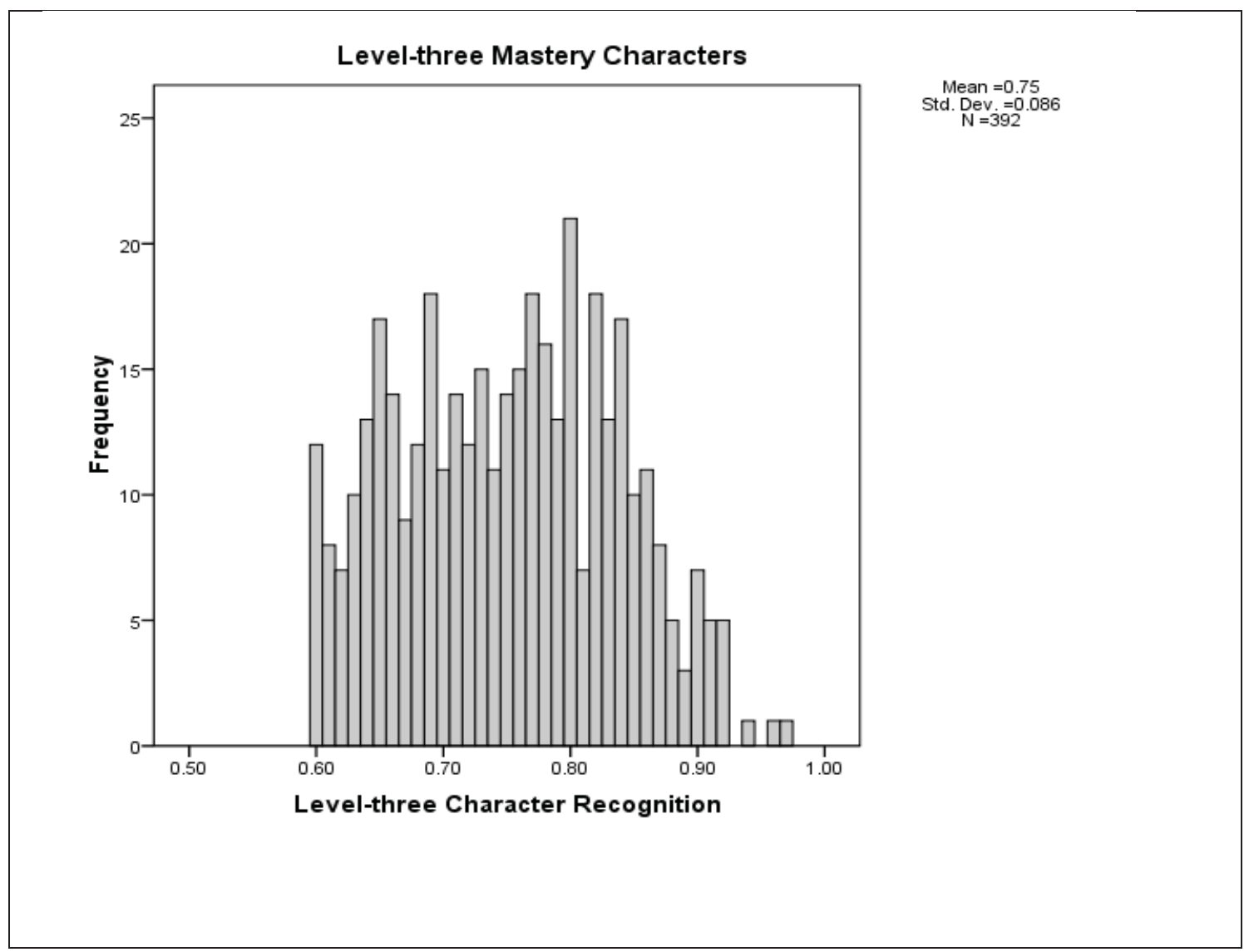

Figure 3. Level-three Mastery Characters 


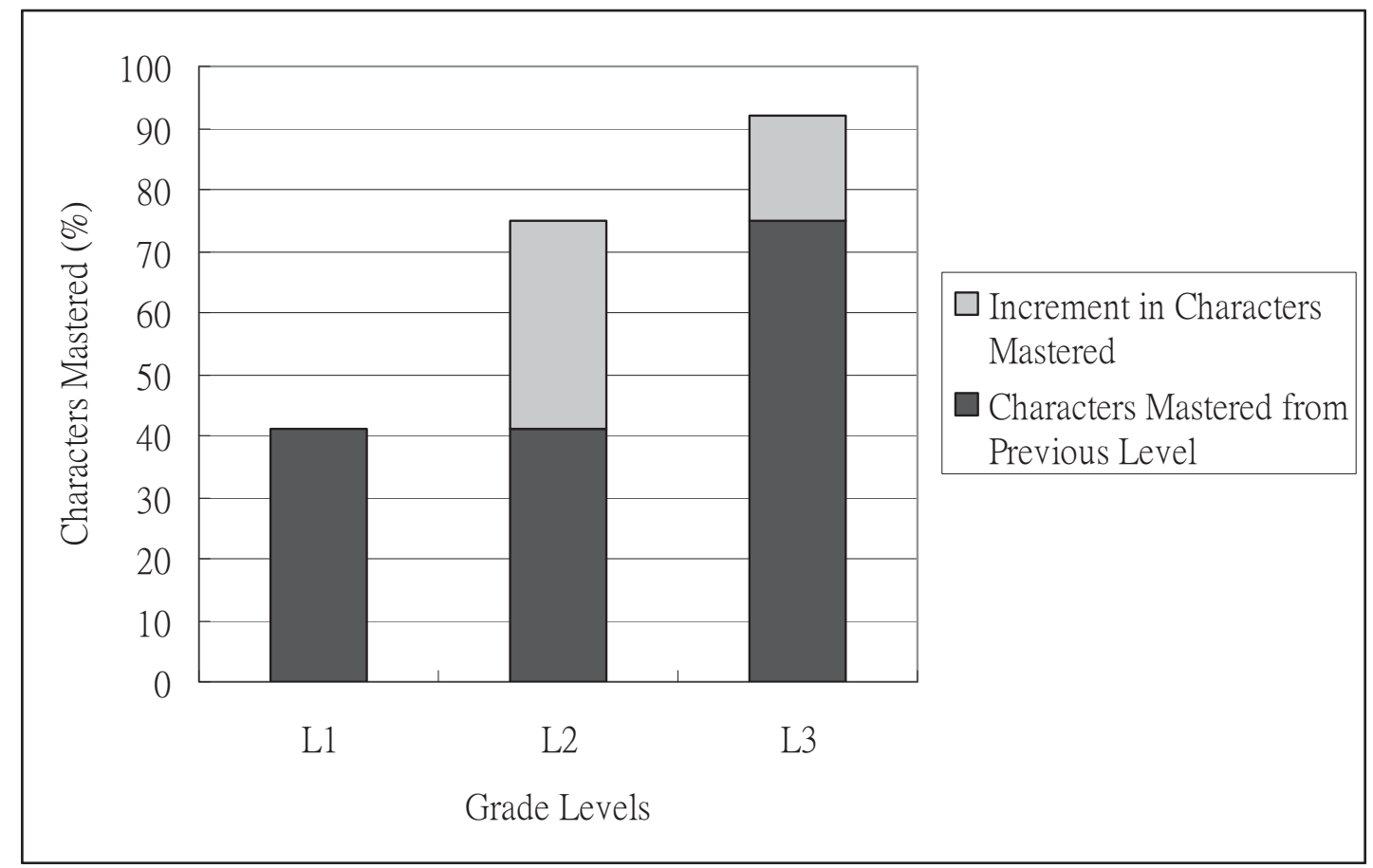

Figure 4. Chinese Character Master and Learning Increment 